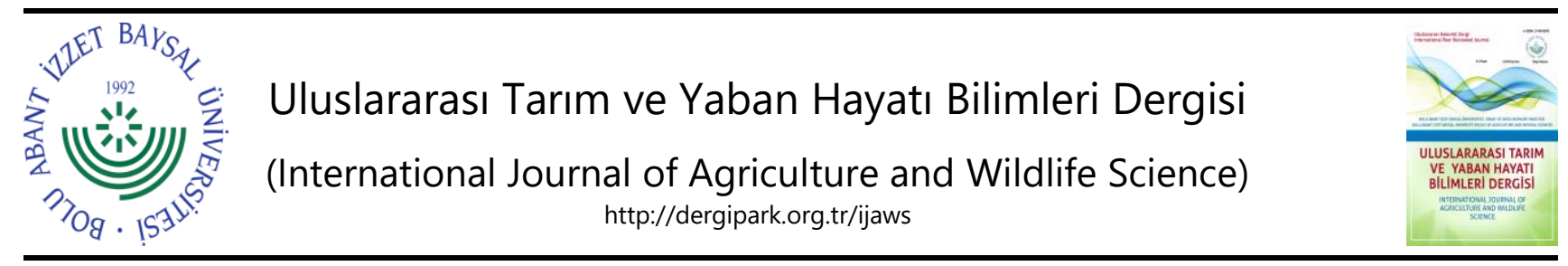

Araştırma Makalesi

\title{
İdil/Şırnak Ekolojisinde Yetiştirilen Yerel Üzüm Çeşitlerinin Etkili Sıcaklık Toplamı İsteklerinin Belirlenmesi
}

\author{
Mehmet Settar Ünal* \\ Şırnak Üniversitesi, Ziraat Fakültesi, Bahçe Bitkileri Bölümü, İdil, Şırnak \\ Geliş tarihi (Received): 13.02.2019 Kabul tarihi (Accepted): 06.05.2019
}

\begin{abstract}
Anahtar kelimeler:
Gelişme süresi, sofralık üzüm, kurutmalık üzüm, etkili sıcaklık toplamı, fenoloji

Özet. Bu çalışma; 2017 ve 2018 yıllarında, Şırnak ili İdil ilçesinde yetiştirilen Misabık, Tayifi, Zeynebi, Raşe gurnik, Payizi, Sinceri, Bilbizeki, Bakari, Kerküş, Zerine, Gawre, Raşe kewnar, Bahdo, Beytilhamam, Goglani, Hasani, Mazrona, Nasiri, Şikari, Zeyti yerel üzüm çeşitlerinde yürütülmüştür. Çalışmada çeşitlerin bazı genel özellikleri, farklı fenolojik safhalara göre gelişme süreleri ve Etkili Sıcaklık Toplamı (EST) değerleri hesaplanmıştır. Araştırma sonucunda, gözlerin uyanması-olgunlaşma dönemleri arasında hesaplanan EST değerleri 1837 gün-derece(Misabık) ile 2942 gün-derece(Mazrone) arasında; gelişme süresi ise 126 gün (Misabık) ve 170 gün (Mazrone) arasında değiştiği belirlenmiştir. EST değerleri yıl ve çeşitlere göre farklılık göstermiştir. Sonuç olarak; "Sıcak İklim" sınıfına giren İdil ekolojisinin ticari değeri yüksek geçci ve kurutmalık üzüm çeşitleri için son derece uygun olduğu ortaya konulmuştur. Şırnak ilinde

*Sorumlu yazar munal61@hotmail.com yetiştirilebilecek ticari değeri yüksek üzüm çeşitlerine ilişkin önerilerde bulunulurken araştırma sonucunda belirlenen EST değerlerine yakın isteği olan üzüm çeşitlerinin önerilmesi ile doğru çeşitler seçilebilecektir.
\end{abstract}

\section{Determination of Effective Heat Summation Requirements of Local Grape Cultivars Grown in Idil Ecology}

\section{Keywords:}

Vegetation period, table grape, dried grape, effective heat summation, phenology

\begin{abstract}
This study were carried out in the Misabık, Tayifi, Zeynebi, Raşe Gurnik, Payizi, Sinceri, Bilbizeki, Bakari, Kerküş, Zerine, Gawre, Raşekewnar, Bahdo, Beytilhamam, Goglani, Hasani, Mazrona, Nasiri, Şikari, Zeyti local grape varieties grown in viticultural area of İil district of Sirnak province in 2017 and 2018. At the end of the research, Effective Head Summation (EHS) values were determined as 1837 degree-days (Misabık)-2942 degree-days (Mazrone) between the bud breaking-ripening periods, while the vegetation period was between 126 days (Misabık)-170 days (Mazrone). The EHS values were varied according to year and variety. As a result; Idil ecology, which is classified as hot climate, has been found to be highly suitable for high value late table grapes and dried grape varieties. While proposing about grape varieties with high commercial value that can be grown in Sirnak province, the right varieties can be selected with the suggestion of grape varieties close to the EHS values determined as a result of the research.
\end{abstract}




\section{GíRiş}

Üzüm yetiştiriciliği; dünyamızın kuzey yarım küresinde $11^{\circ}-53^{\circ}$, güney yarım küresinde ise $20^{\circ}-40^{\circ}$ enlem dereceleri arasında en uygun ekolojik şartlara sahip olup, bu alanlarda yer alan ülkelerde bağcılık yoğun olarak yapılmaktadır. Ancak bu enlemler dışında kutuplara doğru çıkıldıkça sıcaklık toplamı ve donlar, ekvatora doğru yaklaştıkça ise aşırı sıcakların oluşturduğu bazı olumsuzluklardan dolayı yetişme alanları kıııtlanmaktadır (Çelik, 2011).

Yeryüzünde üzüm çeşit ve tip sayısı tahminen 10000 'den fazla olduğu kabul edilmekte ve bu çeşitlerin önemli bir kısmı ülkemizde yer almaktadır (Semerci ve ark., 2015). Ancak ülkemizde yaygın olarak yetiştirilen standart üzüm çeşidi sayısı 80 civarında olduğu bildirilmektedir (Kaya ve Özdemir, 2015).

Türkiye'de 4.170.410 da üretim alanından3.933.000 ton üzüm elde edilmekte olup üretimin \%49.5'ğu sofralık, \%38.7'si kurutmalık ve \%11.8'i şaraplık olarak değerlendirilmekte, verim ise yaklaşık $790 \mathrm{~kg} \mathrm{da}^{-11}$ ı bulmaktadır (TÜIK, 2018).

Bağcılık, ülkemiz ekonomisi için önemli bir tarımsal üretim kolu olup, özellikle diğer tarım ürünlerinin yetiştiriciliğine elverişli olmayan yamaç ve kıraç arazilerin değerlendirilmesinde ve toprak muhafazasında iyi bir erozyon bitkisi olması yanında yoğun bir iş gücü gerektirdiği için yeni iş alanları sağlama bakımından da ayrı bir önemi vardır.

Bağcılık için oldukça uygun iklim yapısına sahip olan ülkemizin, Karadeniz bölgesinin çok yağış alan yöreleri ile İç/Doğu Anadolu bölgelerinin yüksek rakımlı yöreleri hariç, hemen her bölgesinde binlerce yıldır çok sayıda üzüm çeşidinin yetiştiriciliğinin yapılıyor olması üzümün adaptasyon sınıllarının ne kadar geniş olduğunu göstermektedir. Aynı zamanda büyük bir çeşit zenginliğine sahip olduğu için çeşitlerin hasat zamanları arasında bölge ve çeşitlere bağlı olarak 2-5 ay gibi önemli bir farklılık olabilmektedir. Bu üstünlüğün oluşumunda ise iklim unsurları başta olmak üzere arazinin konumu, toprak özellikleri, bakım işlemleri gibi birçok unsur da çeşitlerin hasat zamanını etkilemektedir. Diğer bir ifade ile her üzüm çeşidinin olgunlaşması için gerekli ekolojik istekleri ve uygulanan kültürel uygulamalara olan tepkileri de farklılık göstermektedir.

Bir üzüm çeşidinin herhangi bir bölgede yetişip yetişemeyeceğini, yani ürününü olgunlaştırıp olgunlaştıramayacağını tespit etmede faydalanılan en önemli parametrelerden biri de "Etkili Sıcaklık Toplamı"dır. Her üzüm çeşidinin ürününü olgunlaştırabilmesi için belirli bir sıcaklık toplamına ihtiyaç duyar ve gün-derece (gd) olarak ifade edilen bu değerin hesaplanmasında genellikle, asma tomurcuklarının uyanmaya başladığı ortalama sıcaklık olan $10{ }^{\circ} \mathrm{C}$ esas alınmaktadır. Bu değerin hesaplanmasında gelişme mevsimi boyunca her fenolojik dönem için ayrı ayrı hesaplanabileceği gibi, uyanmadan hasada kadar geçen toplam süre esas alınarak da bulunabilir. Hesaplanan etkili sıcaklık toplamı istekleri göz önünde bulundurularak çeşitler hasat zamanlarına göre sınıflandırılabilirler (Şen, 2008).

Bir bölgede ekonomik anlamda bağcılık yapabilmesi için hesaplanan bu değerin en az $900 \mathrm{gd}$ olması gerekmektedir (Çelik, 2011). Gelişme devresinin kısa olduğu ve kritik sıcaklık değerlerine sahip bölgelerde "Etkili Sıcaklık Toplamı" değerlerinin çeşit seçiminde mutlaka dikkate alınması gerektiği çok sayıda araştırmada bildirilmiştir (Çelik ve ark., 2005; Özdemir ve Tangolar, 2005; Tangolar ve ark., 2005; Alsancak, 2005; Özdemir ve ark., 2006; Cangi ve ark., 2008; Şensoy ve ark., 2009; Kaya ve Özdemir, 2015; Söğüt ve Özdemir, 2015; Küsmüş, 2016; Bekar ve Cangi, 2017). Etkili Sıcaklık Toplamı ihtiyacı yüksek olan ancak yetiştirildiği yöre ekolojisinde bunu karşılayamayan çeşitler istenilen kalite, verim ve gelişmeyi gösteremeyeceklerdir (Şensoy ve ark., 2009).

Şensoy ve ark. (2009)'da yayınladıkları bir çalışmada; üzüm çeşitleri Etkili Sıcaklık Toplamına göre gruplandırılırken çok erkenci çeşitlerin en az $900 \mathrm{gd}$ ve geçci çeşitlerin $1700 \mathrm{gd}$ 'nin üstünde sıcaklık toplamına intiyacı olduğu bildirilmiştir.

Bağcılık yapılan bölgelerde iklim koşullarının çeşitlerin performansına etkisinin ortaya koyulması, daha sonra yapılacak araştırmalar için önemli parametreler sağlamaktadır. Bağcılık yapılan bölgelerde EST değerlerinin belirlenmesi, bölge ekolojisinin yerel çeşitlerin verim ve kalitesine etkisi, ticari çeşitlerin bölgede yetiştirilebilirliği konusunda önemli ipuçları vermektedir.

Araştırmaya konu olan İdil ilçesi, Şırnak illinin bağclık açısından potansiyeli en fazla olan bölgesidir. ì genelinde toplam bağ alanı, üretim miktarı ve verim $30.760 \mathrm{da}, 17.258$ ton ve $561 \mathrm{~kg} \mathrm{da}^{-1}$; İdil'de ise aynı değerler sırayla $19.067 \mathrm{da} \mathrm{( \% 62),} 10.449$ ton (\%60.5)ve $548 \mathrm{~kg} \mathrm{da}^{-1}$ olduğu bildirilmiştir (TÜiK, 2018). Görüldüğü gibi İdil'de bağcılık, il genelinde yapılan bağcılık içerisinde oldukça önemli bir yer tutmaktadır.

Bu bölgede yetiştirilen üzüm çeşitlerinin ampelografik özellikleri (Ünal ve Sevgin, 2017), bu çeşitlerin yapraklarının salamura yapımına uygunluğu (Ünal, 2018) ve değerlendirme şekilleri (Ünal ve Sevgin, 2018) değişik araştırmalarla ortaya konulmuştur. İlçenin iklim yapısı gerek sofralık ve gerekse kurutmalık ve şıralık- 
şaraplık üzüm çeşitlerinin yetiştirilmesine uygundur. Bu çalışmada idil ilçesinde yetiştirilen 19 adet yerel üzüm çeşidinin farklı fenolojik safhalarda EST ve gelişme süreleri saptanmıştır.

\section{MATERYAL VE YÖNTEM}

\section{Materyal}

Araşıırma; 2017 ve 2018 yılları arasında, Şırnak ili İdil ilçesinde bağclığın yoğun olarak yapıldığı Yüksekköy, Haberli ve Öğündük köylerinde yetiştirilen 19 yerel üzüm çeşidi üzerinde yürütülmüştür.

Araştırmaya konu olan yerel üzüm çeşitleri Misabık, Tayifi, Zeynebi, Raşe Gürnik, Payizi, Sinceri, Bilbizeki, Bakari, Kerküş, Zerine, Gawre, R.kewnar, Bahdo, Beytilhamam, Goglani, Hasani, Mazrona, Nasiri, Şikari ve Zeyti'dir. Çeşitlere ait asmalar kendi kökleri üzerinde yetişen ve geleneksel terbiye sistemine(Goble) ait asmalardır.

\section{Metod}

2016 yılında üzümlerin hasat döneminde bağlara gidilerek çeşitlere ait omcalar işaretlenmiştir. 2017 Şubat ayında çeşitlerde sağlıklı gelişen en az 10 adet omca işaretlenmiştir. Asmalar gelişme gücüne ve üreticilerin tecrübelerine göre verim budamasına tabi tutulmuştur. Asmalara gelişme döneminde ek sulama yapılmamış olup, zirai mücadele olarak sadece bordo bulamacı ve toz kükürt üreticiler tarafından uygulanmıştır.

Denemede yer alan üzüm çeşitlerinde fenolojik safhalarda yapılan gözlemlerde uyanma, tam çiçeklenme, ben düşme ve olgunlaşma tarihleri ayrı ayrı kaydedilmiştir. Üzüm çeşitlerinin hasat tarihi, üreticilerin tecrübe ve alışkanlıkları da dikkate alınarak suda çözünür kuru maddenin (SÇKM) \%18-20, şıralık-şaraplık ve kurutmalık çeşitlerde ise \%20-22 orana ulaşmasına dikkat edilmiştir. Ayrıca; uyanma-tam çiçeklenme, tam çiçeklenme-ben düşme ve ben düşme-olgunluk gelişme dönemleri arasında geçen süreler gün olarak saptanmıştır.

EST değerleri farklı fenolojik safhalara göre (uyanma-tam çiçeklenme, tam çiçeklenme-ben düşme, ben düşme-olgunluk ve uyanma-hasat), asmanın gelişme sıcaklık eşiği olarak kabul edilen $10{ }^{\circ} \mathrm{C}$ 'nin üzerindeki sıcaklıklar toplanarak gd olarak hesaplanmıştır. Çeşitlerin bölgedeki yaygınlık durumları ile değerlendirme şekilleri ve salamura yapımına uygunlukları ayrıca verilmiştir (Ünal, 2018).

EST değerlerinin hesaplanmasında İdil Havalimanı Meteoroloji İstasyonu'ndan alınan iki yıllık iklim verileri Çizelge 1'de, araştırmanın yapıldığı köylere ait coğrafik veriler ise Çizelge 2'de verilmiştir.

Çizelge 1. 2017-18 Yılları idil ilçesi aylık ve yıllık ortalama sıcaklık verileri( $\left.{ }^{\circ} \mathrm{C}\right)\left({ }^{*}\right)$.

Table 1. 2017-18 years Idil district monthly and annual average temperature data $\left({ }^{\circ} \mathrm{C}\right)\left({ }^{*}\right)$.

\begin{tabular}{cccccccccccccc}
\hline \multirow{2}{*}{ Yıl } & \multicolumn{10}{c}{ Oylar (**) } \\
\cline { 2 - 14 }$y$ & Oc. & Şb. & Mrt & Nsan & Mys & Haz. & Tem. & Ağt. & Eyl. & Ekim & Ksm & Aralk & Ort. \\
\hline 2017 & 4.2 & 4.3 & 10.6 & 14.7 & 20.9 & 28.5 & 34.0 & 33.2 & 29.3 & 19.3 & 12.6 & 10.1 & $\mathbf{1 8 . 5}$ \\
2018 & 6.3 & 8.5 & 14.0 & 16.8 & 20.4 & 28.3 & 32.9 & 32.5 & 28.5 & 20.8 & 10.3 & 8.1 & $\mathbf{1 7 . 3}$ \\
\hline
\end{tabular}

(*) İdil Hava Limanı Meteoroloji İstasyonu.

(**) 2017 yılı gelişme süresi Mart-Aralık ayı, 2018 yılı gelişme süresi Mart-Kasım ayı.(ort. 8 ay)

Çizelge 2. Araştırma yapılan köylere ait coğrafik veriler.

Table 2. Geographical data of researched villages.

\begin{tabular}{lccc}
\hline \multirow{2}{*}{ Coğrafik veriler } & \multicolumn{3}{c}{ Köyler } \\
\cline { 2 - 4 } & Yüksekköy & Haberli & Öğündük \\
\hline Rakım $(\mathrm{m})$ & 830 & 900 & 820 \\
\multirow{2}{*}{ Koordinatlar } & 37.274994 Enlem & 37.310001 Enlem & 37.340199 Enlem \\
& 41.935745 Boylam & 41.620556 Boylam & 41.893398 Boylam \\
\hline
\end{tabular}

\section{BULGULAR VE TARTIŞMA}

Araştırmaya konu olan Şırnak ilinin iklim yapısı bağcılığa olgun olmakla beraber üzüm yetiştiriciliği yoğun olarak İdil ilçesinde yapılmaktadır. İki yıl süreyle İdil ilçesinde yürütülen çalışmada, 19 yerel üzüm çeşidinde yapılan gözlemler sonrasında kaydedilen fenolojik dönemlere ait bilgiler Çizelge 3'de sunulmuştur. 
Çizelge 3. Üzüm çeşitlerinin fenolojik dönem tarihleri.

Table 3. Phenological period dates of grape cultivars.

\begin{tabular}{|c|c|c|c|c|c|c|c|c|c|}
\hline \multirow{3}{*}{$\frac{\grave{d}}{\bar{d}}$} & \multirow{3}{*}{ Üzüm Çeşitleri } & \multicolumn{8}{|c|}{ Fenolojik Dönemler } \\
\hline & & \multicolumn{2}{|c|}{ Uyanma } & \multicolumn{2}{|c|}{ Tam Çiçeklenme } & \multicolumn{2}{|c|}{ Ben Düşme } & \multicolumn{2}{|c|}{ Olgunluk } \\
\hline & & 2017 & 2018 & 2017 & 2018 & 2017 & 2018 & 2017 & 2018 \\
\hline \multirow{5}{*}{ 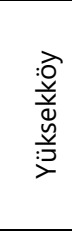 } & Misabık & 29.03 & 26.03 & 13.05 & 16.05 & 05.07 & 07.07 & 03.08 & 04.08 \\
\hline & Bahdo & 30.03 & 28.03 & 13.05 & 16.05 & 10.07 & 14.07 & 10.08 & 11.08 \\
\hline & Bakari & 03.04 & 28.03 & 15.05 & 20.05 & 15.07 & 15.07 & 23.08 & 20.08 \\
\hline & $\begin{array}{l}\text { Zeynebi } \\
\text { (Yarhohe) }\end{array}$ & 03.04 & 30.03 & 15.05 & 19.05 & 20.07 & 20.07 & 28.08 & 25.08 \\
\hline & Bilbizeki & 03.04 & 30.03 & 17.05 & 20.05 & 20.07 & 18.07 & 20.08 & 18.08 \\
\hline \multirow{8}{*}{ 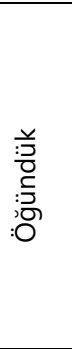 } & Zeyti & 30.03 & 27.03 & 15.05 & 17.05 & 20.07 & 17.07 & 30.08 & 30.08 \\
\hline & Beytilhimam & 02.04 & 28.03 & 15.05 & 18.05 & 18.07 & 15.07 & 23.08 & 25.08 \\
\hline & Raşe gürnik & 03.04 & 28.03 & 20.05 & 20.05 & 30.07 & 27.07 & 15.09 & 20.09 \\
\hline & Payizi & 04.04 & 29.03 & 20.05 & 18.05 & 04.08 & 02.08 & 21.09 & 20.09 \\
\hline & Zerine & 04.04 & 28.03 & 16.05 & 17.05 & 30.07 & 01.08 & 18.09 & 20.09 \\
\hline & $\begin{array}{l}\text { Raşe kewnar } \\
\text { (Gawdone) }\end{array}$ & 30.03 & 27.03 & 18.05 & 15.05 & 25.07 & 21.07 & 10.09 & 10.09 \\
\hline & Kerküş & 07.04 & 03.04 & 20.05 & 23.05 & 05.08 & 10.08 & 25.09 & 30.09 \\
\hline & Gawre & 07.04 & 03.04 & 20.05 & 20.05 & 28.07 & 24.07 & 18.09 & 18.09 \\
\hline \multirow{6}{*}{$\begin{array}{l}\frac{\bar{\Xi}}{\bar{D}} \\
\frac{0}{\pi} \\
\bar{\pi}\end{array}$} & Hasani(Şikari) & 07.04 & 05.04 & 18.05 & 19.05 & 20.07 & 17.07 & 04.09 & 06.09 \\
\hline & Sinceri & 08.04 & 05.04 & 18.05 & 20.05 & 15.07 & 12.07 & 04.09 & 10.09 \\
\hline & Tayifi(Beleki) & 05.04 & 01.04 & 22.05 & 20.05 & 26.07 & 22.07 & 20.09 & 24.09 \\
\hline & Goglani & 10.04 & 04.04 & 22.05 & 22.05 & 19.07 & 15.07 & 10.09 & 15.09 \\
\hline & Nasiri & 10.04 & 08.04 & 25.05 & 22.05 & 20.07 & 16.07 & 05.09 & 30.08 \\
\hline & Mazrone & 10.04 & 08.04 & 30.05 & 24.05 & 05.08 & 10.08 & 01.10 & 05.10 \\
\hline
\end{tabular}

Herhangi bir bitkinin ürününü olgunlaştırabilmesi için belli bir sıcaklık toplamına ihtiyaç duymaktadırlar. Bu sıcaklık toplamının hesaplanmasında bitkinin fenolojik gelişme dönemleri, özellikle uyanma-hasat veya çiçeklenme-hasat süresi göz önünde bulundurulur. Çizelge 3 incelendiğinde, fenolojik dönemlerin oluşum tarihlerinin yıldan yıla ve çeşitten çeşide değiştiği görülmektedir. Ancak iki yıllık çalışmada tespit edilen farklıık, aynı çeşit için tüm dönemlerde yaklaşık 1 hafta olurken çeşitler arasındaki bu farklılık çok daha fazla gerçekleşmiştir. Örneğin; uyanma döneminde 10 gün, tam çiçeklenmede 17 gün, ben düşme döneminde 35 gün ve olgunluk döneminde 62 günü bulmuş ve bu farklılık özellikle ben düşme döneminden itibaren kendisini göstermiş, olgunluk döneminde çeşit özelliği tamamen kendisini belli etmiştir. Ancak bu farklılıkların oluşumunda arazinin konumu, toprak yapısı ve uygulanan kültürel işlemlerin de belli ölçüde etkili olduğunu ifade etmek gerekir. Nitekim Ateş ve Uysal (2017)'da yapmış oldukları çalışmada Narince çeşidini üç farklı ekolojide incelemişler ve uyanma tarihinin, Tokat Merkez ve Niksar ilçelerinde 9 Nisan'da, Erbaa ilçesinde ise 10 Nisan'da gerçekleştiğini kaydederken Bekar ve Cangi (2017) ise tam çiçeklenmenin Tokat merkezde Mayıs'ın son haftası, Erbaa'da Mayıs'ın üçüncü haftası ve Niksar'da Haziran'ın ilk haftası olduğunu tespit etmişlerdir.

Yetiştiricilik açısından ise en önemli fenolojik dönemler, don olaylarından etkilenebileceğinden gözlerin uyanma ve olgunluk (hasat) tarihidir. Dolayısıyla çeşit seçimi yaparken o bölgede oluşan, en az 20 yıllık meteorolojik verilere göre, don tarihlerinin dikkate alınması gerekir.

Bağcılıkta da bir üzüm çeşidinin bir yörede yetişip yetişemeyeceğine karar vermede başvurulan en önemli kıstaslardanbiri de EST olup, üzüm çeşitlerine ait bu değerler Çizelge 4'de verilmiştir.

EST'nın hesaplanmasında göz önünde bulundurulan uyanma ve olgunluk dönemleri, aynı zamanda çeşit seçiminde de, özellikle geç donların ve gelişme döneminin kısa olduğu bölgelerde daha önem arz eder. Şensoy ve ark. (2009); üzüm çeşitlerini Etkili Sıcaklık Toplamı ihtiyacına göre çok erkenci, erkenci, orta mevsim ve son turfanda olarak gruplandıırken bir ekolojide bağcılığa elverişli etkili sıcaklık toplamının alt sınıını $900 \mathrm{gd}$, üst sınıının ise $1700 \mathrm{gd}$.den daha fazla olduğunu belirtmişlerdir. Buna göre Etkili Sıcaklık Toplamı $3416 \mathrm{gd}$ olan bir yörede, her mevsimde olgunlaşabilen üzüm çeşitlerini yetiştirmek mümkün olup, incelenen çeşitler arasında 1837 gd ile Misabık en düşük, 2942 gd ile en yüksek değere sahip olan Mazrone çeşidinin bölgede rahatlıkla yetiştiği görülmektedir (Çizelge 4). Aynı şekilde EST ile yakın ilişkisi olan gelişme dönemi süresi bakımından ortalama olarak 126 gün ile Misabık en kısa, 170 gün ile bölgede en yaygın yetiştirilen Mazrone çeşidi en uzun gelişme dönemine sahiptir (Çizelge 5). Çelik (2011)'e göre bir yörede ekonomik olarak bağcllık yapılabilmesi için gelişme süresinin en az 175 gün olması gerektiği ve inceleme yapılan bağ alanlarının ortalama gelişme sürelerinin(Mart-Kasım)8 ayı içerdiğini (Çizelge 1) dikkate aldığımızda, bölgede her dönemde olgunlaşan üzüm çeşitlerinin yetişebileceği görülmektedir. Bu halde İdil ilçesi EST değerlerine göre "sıcak iklim" sınıfında yer almaktadır. 
Çizelge 4. Çeşitlerin farklı fenolojik gelişme dönemlerine ait EST değerleri (gd).

EHS values of varieties for different phenological development periods (dd).

\begin{tabular}{|c|c|c|c|c|c|c|c|c|c|c|}
\hline \multirow{3}{*}{ Üzüm Çeşitleri } & \multicolumn{10}{|c|}{ Etkili Sıcaklık Toplamı (gd) } \\
\hline & \multicolumn{3}{|c|}{$\begin{array}{c}\text { Uyanma } \\
\text { Tam Çiçeklenme }\end{array}$} & \multicolumn{3}{|c|}{$\begin{array}{l}\text { Tam Çiçeklenme } \\
\text { Ben Düşme }\end{array}$} & \multicolumn{3}{|c|}{$\begin{array}{l}\text { Ben Düşme } \\
\text { Olgunluk }\end{array}$} & \multirow{2}{*}{$\begin{array}{c}\begin{array}{c}\text { Toplam EST } \\
\text { Uyanma- } \\
\text { Olgunluk }\end{array} \\
2017-2018 \\
\end{array}$} \\
\hline & 2017 & 2018 & Ort. & 2017 & 2018 & Ort. & 2017 & 2018 & Ort. & \\
\hline Misabık & 290 & 386 & 335 & 861 & 855 & 858 & 670 & 617 & 644 & 1844 \\
\hline Bahdo & 283 & 378 & 331 & 980 & 1016 & 998 & 712 & 614 & 663 & 1992 \\
\hline Bakari & 291 & 420 & 356 & 1074 & 997 & 1036 & 894 & 794 & 844 & 2236 \\
\hline $\begin{array}{l}\text { Zeynebi } \\
\text { (Yarhohe) }\end{array}$ & 291 & 402 & 347 & 1194 & 1121 & 1158 & 890 & 792 & 841 & 2346 \\
\hline Bilbizeki & 312 & 412 & 362 & 1177 & 1065 & 1121 & 704 & 680 & 692 & 2175 \\
\hline Zeyti & 305 & 393 & 349 & 1194 & 1073 & 1134 & 936 & 973 & 955 & 2438 \\
\hline Beytilhimam & 296 & 399 & 348 & 1146 & 1015 & 1081 & 822 & 907 & 865 & 2294 \\
\hline Raşe gürnik & 345 & 420 & 383 & 1384 & 1271 & 1328 & 986 & 1114 & 1050 & 2761 \\
\hline Payizi & 340 & 395 & 368 & 1477 & 1406 & 1442 & 1029 & 1000 & 1015 & 2825 \\
\hline Zerine & 318 & 389 & 354 & 1403 & 1483 & 1443 & 1043 & 896 & 967 & 2767 \\
\hline $\begin{array}{l}\text { Raşe kewnar } \\
\text { (Gawdone) }\end{array}$ & 337 & 368 & 326 & 1283 & 1182 & 1233 & 1009 & 1066 & 1038 & 2597 \\
\hline Kerküş & 326 & 423 & 375 & 1500 & 1170 & 1335 & 1062 & 1005 & 1034 & 2744 \\
\hline Gawre & 326 & 392 & 359 & 1336 & 1203 & 1270 & 1034 & 1145 & 1090 & 2719 \\
\hline Hasani (Şikari) & 304 & 368 & 336 & 1163 & 1050 & 1107 & 1013 & 1084 & 1049 & 2492 \\
\hline Sinceri & 299 & 378 & 339 & 1043 & 928 & 986 & 985 & 1272 & 1129 & 2454 \\
\hline Tayifi(Beleki) & 358 & 412 & 385 & 1266 & 1157 & 1212 & 1133 & 1302 & 1218 & 2815 \\
\hline Goglani & 333 & 406 & 370 & 1096 & 976 & 1036 & 1153 & 1297 & 1225 & 2631 \\
\hline Nasiri & 367 & 379 & 373 & 1090 & 998 & 1044 & 1033 & 996 & 1015 & 2432 \\
\hline Mazrone & 421 & 400 & 411 & 1321 & 1523 & 1422 & 1159 & 1059 & 1109 & 2942 \\
\hline
\end{tabular}

EST bakımından çeşitler arasında gerek yıldan yıla gerekse aynı yıl içerisinde farklılıkların olduğu belirlenmiştir. Çizelge 4'ü incelediğimizde, Misabık üzüm çeşidinde 2017 yılı EST değeri 1814 gd olurken 2018 yılında 1858 gd olarak görülmüş olup, bu sonuç diğer çeşitler için de tespit edilmiştir. Şensoy ve ark. (2009)'da yapmış oldukları bir çalışmada 420A üzerine aşılı Sultani çekirdeksiz üzüm çeşidinin EST değerlerini 2005 yılında 1251.8 gd, 2006 yılında 1343.6 gd ve 2007 yılında ise $1210 \mathrm{gd}$ olarak bulmuşlardır. Yine Kaya ve Özdemir (2015)'de Diyarbakır'da yaptıkları bir çalışmada EST değerini 2010 yılında Tahannebi'de 1404.7 gd, Şire'de 2577.2 gd, 2011 yılında ise Tahannebi'de 1247.3 gd ve Şire'de $2253.8 \mathrm{gd}$ olarak tespit etmiş olmaları söz konusu farklılıklar üzerinde yılların etkili olabileceğini göstermektedir. Bununla beraber budama, sulama ve gübreleme gibi bakım işlemlerininde EST üzerinde etkili olabileceği göz ardı edilmemelidir.

İdil ilçesinde yetiştiriciliği yapılan üzüm çeşitlerinin fenolojik dönem tarihlerinin yer aldığı Çizelge 3. ' e göre asma gözlerinin uyanması, 2018 yılı mart ayında ortalama sıcaklıkların daha yüksek olmasından dolayı tüm çeşitlerde daha erken olmakla beraber her iki yılda da Mart sonu-Nisan başı olarak gerçekleşmiştir.

Çeşitlere göre fenolojik dönemlerin oluşum tarihlerine bakıldığında ise; uyanma tarihleri çeşit ve yıla göre 1012 gün, tam çiçeklenme 9-17 gün, ben düşme 30-33 gün ve olgunlukta 58-60 günü bulmaktadır (Çizelge 3.; Şekil 1.). Görüldüğü gibi uyanma ve tam çiçeklenme dönemleri arasındaki farklılık çeşitler arasında birbirine yakın iken ben düşmeden (30-33 gün) itibaren bu farklılık artarak olgunlukta (58-60 gün) çok daha bariz olmaktadır. (Leeuwen ve ark., 2004; Şensoy ve ark., 2009; Köse, 2014; Kaya ve Özdemir, 2015; Cangi ve ark., 2008; Cangi ve Altun, 2015; Demir, 2019)'de yaptıkları çalışmalarda benzeri sonuçları almışlardır.

Her iki yılda da Misabık (03.08; 04.08) üzüm çeşidi en önce olgunlaşırken, en geç olgunlaşan çeşit ise Mazrone (1.10; 5.10) olmuştur. Nitekim Ateş ve Uysal (2017)' da yapmış oldukları çalışmada; Narince çeşidini üç değişik çevrede incelemişler ve uyanmanın Tokat Merkez ve Niksar ilçelerinde 9 Nisan'da, Erbaa ilçesinde ise 10 Nisan'da gerçekleştiğini kaydetmişlerdir. Cangi ve ark. (2008) yapmış oldukları çalışmada tam çiçeklenmenin 2006 yılı Haziran'ın ikinci haftasında, 2007 yılı Haziran'ın ilk haftasında; hasat tarihinin ise 2006 yılında 19 Eylül, 2007 yılında ise 29 Eylül tarihinde olduğunu belirtmişlerdir. Kaya ve Özdemir (2015)'de Diyarbakır'da yürüttükleri bir çalışmada 2010 yılında en erken uyanan çeşitlerin Genç Mehmet, Tahannebi ve Tilki kuyruğu olduğunu, 2011 yılında ise Cirbet olduğunu tespit etmişlerdir. 
Çizelge 5. Üzüm çeşitlerinin gelişme süresi ve bazı özellikleri (2018-19).

Table 5. Vegetation periods of Grape varieties and some properties (2018-19).

\begin{tabular}{|c|c|c|c|c|c|c|c|}
\hline \multirow[b]{2}{*}{$\begin{array}{l}\text { Üzüm } \\
\text { çeşitleri }\end{array}$} & \multicolumn{4}{|c|}{ Gelişme Süresi (gün) } & \multicolumn{3}{|c|}{ Çeşitlerin Bazı Özellikleri } \\
\hline & $\begin{array}{c}\text { Uyanma } \\
\text { T. Çiçekl. } \\
\text { (ort.) }\end{array}$ & $\begin{array}{l}\text { T. Çiçekl. } \\
\text { B. Düşme } \\
\text { (ort.) }\end{array}$ & $\begin{array}{l}\text { B. Düşme } \\
\text { Olg. (ort.) }\end{array}$ & Toplam & $\begin{array}{l}\text { Yaygınlık } \\
\text { Durumu }\end{array}$ & $\begin{array}{l}\text { Kullanım } \\
\text { Şekli }\end{array}$ & $\begin{array}{c}\text { Yaprağın } \\
\text { Salamuraya } \\
\text { Uygunluğu } \\
\end{array}$ \\
\hline Misabık & 47 & 52 & 28 & 126 & Çok az & Sofralık & Uygun değil \\
\hline $\begin{array}{l}\text { Bahdo } \\
\text { (Bahdoki) }\end{array}$ & 46 & 56 & 33 & 134 & Çok az & Sofralık & Uygun \\
\hline Bakari & 47 & 58 & 37 & 141 & Orta & Sofralık & Uygun \\
\hline $\begin{array}{l}\text { Zeynebi } \\
\text { (Yarhohe) }\end{array}$ & 46 & 63 & 34 & 143 & Orta & $\begin{array}{c}\text { Sofralık } \\
\text { Kurutmalık }\end{array}$ & Uygun değil \\
\hline Bilbizeki & 47 & 61 & 37 & 144 & Çok yaygın & $\begin{array}{c}\text { Sofralık } \\
\text { Kurutmalık }\end{array}$ & Uygun değil \\
\hline Zeyti & 48 & 63 & 40 & 150 & Çok az & $\begin{array}{c}\text { Sofralık } \\
\text { Kurutmalık }\end{array}$ & Uygun değil \\
\hline Beytilhimam & 47 & 60 & 49 & 156 & Çok az & Sofralık & Uygun değil \\
\hline Raşe gürnik & 50 & 69 & 44 & 162 & Çok az & $\begin{array}{l}\text { Sofralık } \\
\text { Şıralık }\end{array}$ & Uygun değil \\
\hline Payizi & 48 & 77 & 48 & 172 & $\mathrm{Az}$ & Sofralık & Uygun değil \\
\hline Zerine & 47 & 75 & 48 & 169 & $\mathrm{Az}$ & Sofralık & Uygun değil \\
\hline $\begin{array}{l}\text { Raşe kewnar } \\
\text { (Gawdone) }\end{array}$ & 48 & 67 & 48 & 162 & Yaygın & $\begin{array}{c}\text { Sofralık } \\
\text { Şıralık Şaraplık } \\
\text { Kurutmalık }\end{array}$ & Uygun değil \\
\hline Kerküş & 47 & 61 & 52 & 160 & Çok yaygın & $\begin{array}{c}\text { Sofralık } \\
\text { Kurutmalık }\end{array}$ & Uygun değil \\
\hline Gawre & 45 & 66 & 50 & 161 & Çok az & Sofralık & Uygun \\
\hline $\begin{array}{l}\text { Hasani } \\
\text { (Şikari) }\end{array}$ & 43 & 60 & 53 & 156 & Çok az & $\begin{array}{c}\text { Sofralık } \\
\text { Kurutmalık }\end{array}$ & Uygun değil \\
\hline Sinceri & 43 & 55 & 59 & 156 & $\mathrm{Az}$ & $\begin{array}{c}\text { Sofralık } \\
\text { Şıralık Şaraplık }\end{array}$ & Uygun değil \\
\hline $\begin{array}{l}\text { Tayifi } \\
\text { (Beleki) }\end{array}$ & 49 & 63 & 57 & 169 & Çok az & Sofralık & Uygun \\
\hline Goglani & 45 & 55 & 48 & 148 & Çok az & $\begin{array}{c}\text { Sofralık } \\
\text { Kurutmalık }\end{array}$ & Uygun değil \\
\hline Nasiri & 45 & 65 & 55 & 164 & Çok az & $\begin{array}{c}\text { Sofralık } \\
\text { Kurutmalık }\end{array}$ & Uygun değil \\
\hline Mazrone & 48 & 71 & 51 & 170 & Çok yaygın & $\begin{array}{c}\text { Sofralık } \\
\text { Şıralık Şaraplık }\end{array}$ & Uygun değil \\
\hline
\end{tabular}

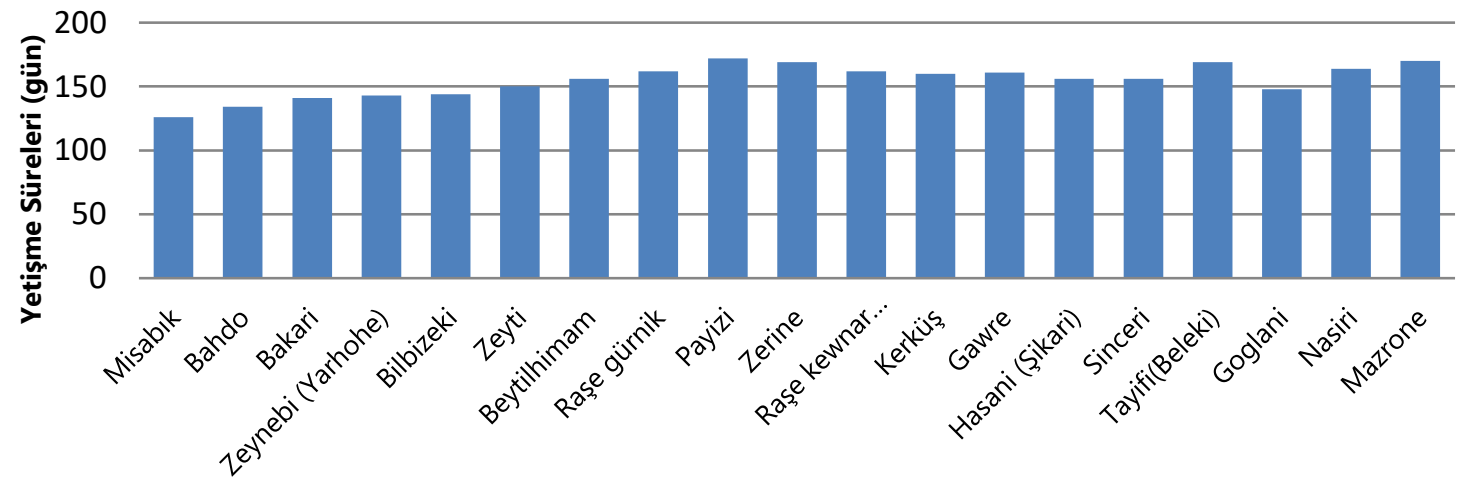

Yerel Üzüm Çeşitleri

Şekil 1. Üzüm çeşitlerinde gözlerin uyanmasından hasada kadar geçen süre (gün).

Figure 1. Bud burst to harvest periods of grape varieties (day).

Bilindiği gibi canlılarda karakterlerin oluşumu ve gelişimi, birçok faktörün etkisi altında oluşmaktadır. Konuyu bu bağlamda ele alırsak EST'de öncelikle bir çeşit özelliği olmakla beraber iklim faktörleri, bağın içerisinde bulunduğu arazinin konumu, toprağın fiziksel ve kimyasal özellikleri, rakım ve bakım işlemlerindeki farklılıklar da etkili olabilmektedir. Örneğin; Bekar ve Cangi (2017) yaptıkları bir çalışmada, Narince üzümünde EST'nin Tokat merkezde $1885.91 \mathrm{gd}$, Erbaa'da $1842.96 \mathrm{gd}$ ve Niksar'da $1908.81 \mathrm{gd}$ olarak tespit etmesi rakım ve çevre 
faktörünün; Şensoy ve ark. (2009)'nın yaptıkları bir çalışmada EST'nin Sultani çekirdeksiz/420A'da 1264.5 gd, Sultani çekirdeksiz/110R'de ise $1363.8 \mathrm{gd}$ olarak bildirmeleri anacın etkisinin olduğunu akla getirmektedir.

Çizelge 5. incelendiğinde, yöre bağlarında kırk ambar usulü (karışık) yetiştiricilik yapıldığı, ancak Mazrone, Kerküş gibi 1-2 çeşidin bağlarda hakim olduğunu göstermektedir. Elde edilen ürün çoğunlukla taze tüketimde değerlendirilmekle beraber kuru üzüm, pekmez-pestil gibi ürünlerin yapımına ilaveten azda olsa şarap yapımında da kullanılmaktadır. Mevcut çeşitler içinde salamura yapımına uygun (ince, tüysüz, tüm ve damarsız yaprağa sahip) çeşitlerin (Bahdo, Bakari, Tayifi, Gawre) sayısının çok az olduğu görülmektedir.

\section{SONUÇ}

Çalışma sonucunda incelenen tüm özellikler yıllara ve çeşitlere göre değişiklikler göstermiş̧tir. Araştırma sonucunda Şırnak ili i̇dil ekolojik koşullarında yetiştirilen üzüm çeşitlerinin ortalama EST değerlerinin $1837 \mathrm{gd}$ (Misabık) ile 2942 gd (Mazrone) arasında değiş̧iği belirlenmiştir. İdil ilçesi ekolojisinin "Sıcak İklim" grubunda yer aldığı, geçci ve kurutmalık üzüm çeşitlerinin bu EST değerlerine göre rahatlıkla yetişebileceği görülmüştür. Şıralık-Şaraplık üzüm çeşitlerinin istenilen kalitede olup olmayacağı, olgunluk döneminde çeşitlerin biyokimyasal içeriğinin takip edilmesi ve elde edilecek ürünlerin fiziksel, kimyasal ve duyusal değerlendirme sonrası anlaşılabileceği söylenebilir.

İdil'de ticari değeri yüksek yerel çeşitlerin belirlenerek bu çeşitlerle bağ alanlarının genişletilmesi, kalite ve verime yönelik çalışmaların yoğunlaştıııması gerekir. Ayrıca, Suriye ve Irak pazarına hitap edecek ticari sofralık çeşitlerle adaptasyon bağlarının bir an önce kurulması değerlendirilebilir.

\section{KAYNAKLAR}

Alsancak, B. (2005). Gediz havzasında iklim isteklerine göre farklı üzüm çeşitlerinin yetiştirilebileceği alanların belirlenmesi. Yüksek Lisans Tezi, Ankara Üniversitesi, Fen Bilimleri Enstitüsü, Ankara.

Ateş, F., \& Uysal, H. (2017). Determinationsof adaptation level of wine grape varieties in terms of climatic data in wine growing regions of turkey. 40th World Congress of Vine and Wine, Bulgaria.

Bekar, T., \& Cangi, R. (2017). Tokat'ta farklı ekolojilerde yetiştirilen narince üzüm çeşidinin fenolojik gelişme evreleri ve etkili sıcaklık toplamı isteklerinin belirlenmesi. Türkiye Teknoloji ve Uygulamalı Bilimler Dergisi, 1(2), 86-90.

Cangi, R., Şen, A., \& Kıııç, D. (2008). Bazı üzüm çeşitlerinin Kazova (Tokat-Turhal) koşullarındaki fenolojik özellikleri ile etkili sıcaklık toplamı (EST) isteklerinin saptanması. Tarım Bilimleri Araştırma Dergisi, 2, 45-48.

Cangi, R., \& Altun, M. A. (2015). Bazı önemli sofralık üzüm çeşitlerinin Sakarya/Taraklı ekolojisine adaptasyonu. Tarım Bilimleri Araştırma Dergisi, 8(2), 35-39.

Çelik, H., Çetiner, H., Söylemezoğlu, G., Kunter, B., \& Çakır, A. (2005). Bazı üzüm çeşitlerinin kalecik koşullarındaki fenolojik özellikleri ile etkili sıcaklık toplamı (EST) isteklerinin belirlenmesi. 6. Türkiye Bağclık Sempozyumu, Tekirdağ Bağcılık Araştırma Enstitüsü, Tekirdağ.

Çelik, S. (2011). Bağcllık (Ampeloloji). Namık Kemal Üniversitesi, Ziraat Fakültesi, Bahçe Bitkileri Bölümü, Cilt 1, Tekirdağ.

Demir, E. (2019). Mecitözü ekolojisinde yetiştirilen bazı üzüm çeşitlerinde optimum hasat zamanlarının belirlenmesi. Yüksek Lisans Tezi, T.C. Gaziosmanpaşa Üniversitesi, Fen Bilimleri Enstitüsü, Tokat.

Kaya, M., \& Özdemir, G. (2015). Bazı sofralık üzüm çeşitlerinin diyarbakır koşullarındaki kalite özellikleri ile etkili sıcaklık toplamı isteklerinin belirlenmesi. Selçuk Üniversitesi, Selçuk Tarım ve Gıda Bilimleri Dergisi, 27(Özel Sayı).

Köse, B. (2014). Phenology and ripening of Vitis vinifera L. and Vitis labrusca L. varieties in the Maritime 324 climate of Samsun in Turkey's Black Sea Region. South African Journal of Enology and Viticulture, 35(1), 325 90-102.

Küsmüş, S. (2016). Malatya ilinde yetiştirilen üzüm çeşitlerinde etkili sıcaklık toplamı ve optimal hasat zamanlarının belirlenmesi. Yüksek Lisans Tezi, Yüzüncü Yıl Üniversitesi Fen Bilimleri Enstitüsü, Van.

Leeuwen, V., Friant, P., Chone, X., Treqoat, O., Koundouras, S., \& Doburdiev, D. (2004). Influence of climate, soil, 329 and cultivar on terroir. American Journal of Enology and Viticulture, 55(3), 207-217.

Özdemir, G., \& Tangolar, S. (2005). Diyarbakır ve Adana koşullarında yetiştirilen bazı sofralık üzüm çeşitlerinde fenolojik devreler ile etkili sıcaklık toplamı değerleri ve bazı kalite özelliklerinin belirlenmesi. Türkiye 6 . Bağcılık Sempozyumu, Tekirdağ Bağcılık Araştırma Enstitüsü, Tekirdağ.

Özdemir, G., Tangolar, S., \& Bilir, H. (2006). Bazı sofralık üzüm çeşitlerinin fenolojik dönemleri ile salkım ve tane özelliklerinin saptanması. Alatarım, 5(2), 37-42. 
Semerci, A., Kızıltuğ, T., Çelik, A. D., \& Kiracı, M. A. (2015). Türkiye bağcıllı̆ının genel durumu. Mustafa Kemal Üniversitesi Ziraat Fakültesi Dergisi, 20(2), 42-51.

Söğüt, A. B., \& Özdemir, G. (2015). Bazı şaraplık üzüm çeşitlerinin Diyarbakır ekolojisindeki fenolojik özellikleri ile etkili sıcaklık toplamı isteklerinin belirlenmesi. Selçuk Tarım ve Gıda Bilimleri Dergisi, 27, 403-412.

Şen, A. (2008). Kazova (Tokat) ekolojisinde yetiştirilen bazı üzüm çeşitlerinde etkili sıcaklık toplamı ve optimum hasat zamanlarının belirlenmesi. Yüksek Lisans Tezi, Gaziosmanpaşa Üniversitesi, Fen Bilimleri Enstitüsü, Tokat.

Şensoy, R. İ. G., Balta, F., \& Cangi, R. (2009). Bazı sofralık üzüm çeşitlerinin van ekolojik koşullarındaki etkili sıcaklık toplamı değerlerinin belirlenmesi. Harran Üniversitesi Ziraat Fakültesi Dergisi, 13(3), 49-59.

Tangolar, S., Özdemir, G., Bilir, H., \& Sabır, A. (2005). Bazı üzüm çesitlerinin Pozantı/Adana koşullarında fenolojileri ile salkım ve tane özelliklerinin saptanması. Türkiye 6. Bağcılık Semineri, Tekirdağ Bağcılık Araştırma Enstitüsü, Tekirdağ.

TÜiK. (2018). Bitkisel Üretim İstatistikleri. https://biruni.tuik.gov.tr. Erişim tarihi: 18 Nisan 2019.

Ünal, M. S., \& Sevgin, N. (2017). Idil/Şırnak yöresi üzüm çeşitleri ve bazı ampelografik özellikleri. 2. Uluslararası Akdeniz Bilim ve Mühendislik Kongresi, IMSEC 2017, Adana.

Ünal, M. S. (2018). Idil Bölgesi üzüm çeşitlerinin salamura yaprak yapımına uygunluğunun araştırılması. Şehr-i Nuh Uluslararası Multidisipliner Çalışmalar Kongresi, Cizre-Şırnak.

Ünal, M. S., \& Sevgin, N. (2018). Evaluation methods of grape varieties produced in Idil/ ŞIRNAK region. Poster Presentation. I. International Agricultural Science Congress, Van. 